\title{
The Influence of the Chairman of Education Department on the Performance of the Head of Junior High Schools in Ogan Ilir District
}

\author{
Novita Susanti $^{1 *}$, Syarwani Ahmad ${ }^{2}$, Achmad Wahidy $^{2}$ \\ ${ }^{1}$ SMP Negeri 1 Sungai Pinang \\ ${ }^{2}$ Universitas PGRI Palembang \\ *Corresponding author. Email: novieismed2000@gmail.com
}

\begin{abstract}
The goal of this research is to determine the effect of the head of the education office on the performance of school principals. This research was conducted at SMP Negeri Ogan Ilir Regency. This type of data is collected quantitative data analysis. While the study method used is quantitative design methods. The sample in this study was the principal and teachers of the Ogan Ilir District Junior High School, totaling 52 participants. The information gathering methods used in this research were surveys, analysis and documentary evidence. The $t$ test and the $\mathrm{F}$ test were used in the data analysis technique. The study result revealed there was a partial or simultaneous influence on the performance of the headmaster of SMP Negeri in Ogan Ilir Regency by the headmaster of the Education Office and the motivation.
\end{abstract}

Keywords: Leadership, Motivation, Principal Performance

\section{INTRODUCTION}

The issue of leadership often gives a positive impact, since an institution will succeed or will struggle to be partially determined by the great leader. Leadership is the ability to influence and drive and direct action on a person or a group of people to achieve certain objectives in certain situations. Leadership is one of the key management aspects of organizational life. Kartini et al note that there is a major influence on the success of teachers between principal leadership, academic supervision and professional competence at the same time [1]. Since this management of the leader acts as a harmonizer in the spirit of teamwork between people within their institutions [2].

The head of the education office manages all available resources effectively and efficiently to achieve the goals of the organization he leads. With a new paradigm shift in education, a change in the leadership paradigm of the head of a professional education office is also needed. Education is the most significant predictor for the growth of a [3]. To answer various problems faced by the agency, the leadership pattern is one of the choices for the head of the department to lead and develop a quality agency. In leading leadership, one must have a clear vision and mission, use effective communication, provide intellectual stimulation and personal attention to the individual problems of the members of the organization [4].

With the proper functioning of leadership management, it is believed that the institutions they lead will experience development and improvement in the quality of education [5]. To clarify the problems that will be investigated with the following problem formulations regarding the influence of the head of the education office on improving the performance of the Heads of State Junior High Schools in Ogan Ilir Regency, the influence of motivation on improving the performance of the head of SMP Negeri in Ogan Ilir Regency, the influence of the leadership of the head of the education office and motivation to increase the performance of the head of the State Junior High School in Ogan Ilir Regency.

The goal of this research and describe the influence of the leadership of the head of the education office on improving the performance of the Headmaster of Junior High Schools (SMP) in Ogan Ilir Regency, knowing and describing the influence of motivation on improving the performance of junior high school (SMP) principals in Ogan Ilir Regency, knowing and describing the influence of the leadership of the head of the education and culture office and motivation on improving the performance of the principal of Junior High Schools (SMP) in Ogan Ilir Regency. 


\section{METHODS}

This study uses a quantitative research design. Quantitative research is used to see the effect partially between the existing variables [6]. Methodology is a determining factor for the merits of writing scientific papers [7]. The objective of research is to develop and apply statistical formulas, concepts or theories associated with natural hypotheses [8]. This same data analysis factors examined in this research consisted of leadership $\left(\mathrm{X}_{1}\right)$ on performance $(\mathrm{Y})$, motivation $\left(\mathrm{X}_{2}\right)$ on performance $\left(\mathrm{X}_{2}\right)(\mathrm{Y})$. While carrying out this study together (simultaneously), namely leadership $\left(\mathrm{X}_{1}\right)$ and motivation $\left(\mathrm{X}_{2}\right)$ for performance $(\mathrm{Y})$, all the data collected are stored and analyzed using a statistical approach.

\section{RESULTS AND DISCUSSION}

The leadership of the head of the education office and work motivation are components that can affect the performance of school principals in education. This component of course has an impact on the results of the principal's work if it is carried out in accordance with established procedures. The leadership of the head of the department provides guidance to the principal which will have an impact on the progress of the school, while work motivation contributes to the activities of the principal to improve the quality of education in schools, so that these two aspects can mutually influence the performance of the principal. In this research, departmental leadership variable and job motivation together have an effect on improving the performance of school principals. The Principal should be capable of carrying out inventions, be able to direct all stakeholders and the school as an education institution [8]. The principal is the driving factor in realizing the vision, mission, including goals [9].

Work motivation is one of the factors that can affect the performance of school principals in an institution, especially in terms of education depending on the outcomes of the hypothesis tests, it illustrates that the motivation for work has a direct influence on the performance of the principal. The teacher will demonstrate an interest in carrying out a task or event and then do it well if there is a motivating force, namely motivation [10]. Work motivation is the driving force or driving force both from within (internal) and from outside (externally) which creates a desire to carry out an activity or activity in carrying out duties as a leader in the school. So, the encouragement that exists within the Principal can come from within or from outside himself in line with his desire to meet his needs. Work motivation is an impetus for the principal to be willing to work hard and sincerely in order to achieve the desired goals. Motivation is needed for everyone to carry out activities or work. Motivation arises from the existence of several unfulfilled needs that cause pressure or a sense of dissatisfaction that encourages the creation of a good performance of the principal.

Output data of the simple linear regression test, the Fcount valuation is greater than the Ftable value, which means that there is a significant influence on the leadership of the head of the education office and work motivation on the performance of the principal of SMP Negeri Ogan Ilir Regency. The data for the appropriate option of the independent variable to a value of the dependent variable described are the results of the field statistical analysis that reflect the effectiveness of the variable leadership implementation of the head of the education office and work motivation on the performance of the headmaster of the Ogan Ilir Regency State school.

The factor that affects the increase in the performance of school principals is the leadership of the head of the education office. The head of the department has a main role in carrying out the main duties as executor of government administration in the education sector. The head of the education office is required to be professional in carrying out tasks, in the sense that he must master well his field of work and have high moral commitment. As a leader, the head of the education office is a subject who must carry out his leadership through guidance, guidance and empowerment to the entire community. In this case, providing guidance to the performance of school principals in improving the quality of education. The less than satisfactory output of teachers in schools is not solely due to the skill of the teachers themselves. Many factors influence the success of teachers, both external and internal [11].

\section{CONCLUSION}

On the basis of data analysis and the hypothesis testing, the data that will be gathered: 1) there is an influence of the leadership of the head of the education and culture office on the performance of the head of the Ogan Ilir District Middle School; 2) there is an influence of the work motivation of the head of the education and culture office on the performance of the head of the Ogan Ilir District Junior High School, and 3 ) there is an influence of the leadership of the Head of the Education Office and work motivation together on the performance of the head of the SMP Negeri Ogan Ilir Regency.

\section{ACKNOWLEDGMENT}

Our deepest gratitude goes to Teachers in SMP Negeri 1 Sungai Pinang, Chancellor of Palembang PGRI University, Director of the Postgraduate Program of PGRI Palembang University and the Education Management Study Program of PGRI Palembang University, who have supported us in doing this extraordinary thing. This project is funded independently. We also want to thank our Education 
Management friends who helped us a lot in a short time frame to complete this project.

\section{REFERENCES}

[1] Kartini, D., Kristiawan, M., \& Fitria, H. (2020). The Influence of Principal's Leadership, Academic Supervision, and Professional Competence toward Teachers' Performance. Education and Training for Strengthening Principal to Effective Schools. International Journal of Progressive Sciences and Technologies (IJPSAT), 20(1).

[2] Djamarah, S. B. (2011). Teaching and Learning Strategies. Jakarta: Rineka Cipta.

[3] Asvio, N., Yamin, M., \& Risnita. (2019). Influence of Leadership Style, Emotional Intelligence and Job Satisfaction toward Organizational Commitment (Survey at SMA Muhammadiyah South Sumatera). International Journal of Scientific \& Technology Research 8 (8).

[4] Sugiyono. (2014). Educational Research Statistics. Bandung: CV Alfabeta.

[5] Hendriyadi, Ritonga, A. H., \& Us, K. A. (2020). Management Leadership in Improving the Quality of Graduates of Private Islamic Religious Colleges in Jambi Province. International Journal of Progressive Sciences and Technologies (IJPSAT) Vol. 23 No. 2 November 2020, pp. 42-51 Retrieved from https://ijpsat.ijsht-

journals.org/index.php/ijpsat/article/view/2308

[6] Uno, H B. (2011). Motivation Theory and Its Measurement. Jakarta: Earth Literacy.

[7] Muttaqin, K., \& Rahmadoni, J. (2020). Analysis And Design of File Security System AES (Advanced Encryption Standard) Cryptography Based. Journal of Applied Engineering and Technological Science (JAETS), 1(2), 113-123. https://doi.org/10.37385/jaets.v1i2.78

[8] Andriani, S., Kesumawati, N., \& Kristiawan, M. (2018). The Influence of the Transformational Leadership and Work Motivation on Teachers Performance. International Journal of Scientific \& Technology Research, 7(7).

[9] Handayani, D. O., Kristiawan, M., \& Destiniar. (2020). Education and Training for Strengthening Principal to Effective Schools. International Journal of Progressive Sciences and Technologies (IJPSAT), 22(1), 321-326.
[10] Darmiati, D., Kristiawan, M., \& Rohana, R. (2020). The Influence of School Leadership and Work Motivation toward Teacher's Discipline. Journal of Social Work and Science Education, 1(1), 32-44. Retrieved from https://ejournal.karinosseff.org/index.php/jswse/ article/view/8

[11] Maryati, E., Fitria, H., \& Rohana, R. (2020). The Influence of Principal's Leadership Style and Organizational Culture on Teacher's Performance. Journal of Social Work and Science Education, 1(2), 127-139. Retrieved from https://ejournal.karinosseff.org/index.php/jswse/ article/view/38 